\title{
Association of breastfeeding with asthma in young Aboriginal children in Canada
}

\author{
Ming Ye MSc ${ }^{1}$, Piushkumar J Mandhane MD PhD², Ambikaipakan Senthilselvan PhD ${ }^{1}$
}

\begin{abstract}
M Ye, PJ Mandhane, A Senthilselvan. Association of breastfeeding with asthma in young Aboriginal children in Canada. Can Respir J 2012;19(6):361-366.
\end{abstract}

BACKGROUND: Few studies have investigated the factors associated with asthma in young Aboriginal children.

OBJECTIVE: To characterize the association of demographic, environmental and early life factors with asthma in young Aboriginal children in Canada.

METHODS: The 2006 Aboriginal Children's Survey was conducted among off-reserve Aboriginal children zero to six years of age to obtain information on Aboriginal children's development and well-being. The prevalence of asthma in Aboriginal children was obtained from the parental report of asthma as diagnosed by a health care professional.

RESULTS: The prevalence of reported asthma among off-reserve Aboriginal children zero to six years of age $(n=14,170)$ was $9.4 \%$. Asthma prevalence in both exclusively breastfed children $(6.8 \%)$ and ever but not exclusively breastfed children (9.0\%) was significantly lower than that in nonbreastfed children (11.0\%). In the multiple logistic regression analysis, exclusive breastfeeding was protective of asthma compared with nonbreastfeeding (OR 0.59 [95\% CI 0.44 to 0.78]). Older age groups, male sex, having two or more older siblings, low birth weight, day care attendance and ear infection were significant risk factors for asthma.

CONCLUSIONS: The prevalence of asthma among young Aboriginal children zero to six years of age living off reserve was slightly lower than that reported for all other Canadian children. Breastfeeding, especially exclusively breastfeeding, was protective of asthma in Aboriginal children, which is consistent with what has been observed in non-Aboriginal children in Canada. Public health interventions intended for reducing asthma incidence in young Aboriginal children should include breastfeeding promotion programs.

Key Words: Aboriginal; Asthma; Breastfeeding; Children; Prevalence

A ccording to the 2006 census, the Aboriginal child population is Agrowing faster than other Canadian children (1). Asthma was one of the most common chronic health conditions in Métis and Inuit children zero to six years of age in the analysis of the 2006 Aboriginal People's Survey (2,3). A Canadian cohort study of children zero to 11 years of age reported that early childhood factors, such as breastfeeding, maternal smoking, day care attendance, being the first born child and living in rural areas, were associated with the incidence of asthma and asthma-like symptoms (4). In studies conducted in the United States and Australia, breastfeeding was associated with a reduced risk of asthma in children $<6$ years of age, especially in children $<24$ months $(5,6)$. A birth cohort study in Arizona (USA) found that the relationship between breastfeeding and asthma was dependent on the age of the child and atopy status (7). A recent analysis of the data from the International Study of Asthma and Allergies in Childhood (ISAAC-Phase III), which involved 206,453 children six to seven years of age at 72 centres in 31 countries, suggested no consistent association between breastfeeding in infancy and asthma symptoms (8). However, limited information is available on the prevalence of asthma and factors associated with asthma, especially breastfeeding,

\section{L'association de l'allaitement à l'asthme chez les jeunes enfants autochtones du Canada}

HISTORIQUE : Peu d'études ont porté sur les facteurs associés à l'asthme chez les jeunes enfants autochtones.

OBJECTIF : Caractériser l'association des facteurs démographiques, environnementaux et de début de vie à l'asthme chez les jeunes enfants autochtones du Canada.

MÉTHODOLOGIE : L'Enquête sur les enfants autochtones de 2006 a été menée auprès des enfants autochtones hors réserve de zéro à six ans afin d'obtenir de l'information sur le développement et le bien-être des enfants autochtones. La prévalence d'asthme chez les enfants autochtones provenait de la déclaration d'asthme par les parents, tel qu'il avait été diagnostiqué par un professionnel de la santé.

RÉSULTATS : La prévalence d'asthme déclaré chez les enfants autochtones hors réserve de zéro à six ans $(\mathrm{n}=14170)$ s'élevait à 9,4\%. La prévalence d'asthme chez les enfants allaités exclusivement (6,8 \%) et chez les enfants déjà allaités, mais pas exclusivement $(9,0 \%)$, était considérablement plus faible que chez les enfants non allaités (11,0\%). Dans l'analyse de régression logistique multiple, l'allaitement exclusif protégeait contre l'asthme par rapport au non-allaitement (RRR 0,59 [95\% IC 0,44 à 0,78$]$ ). Les groupes plus âgés, le sexe masculin, le fait d'avoir au moins deux frères ou sœurs plus âgés ou un petit poids de naissance, la fréquentation d'un milieu de garde et l'otite étaient d'importants facteurs de risque de l'asthme.

CONCLUSIONS : La prévalence d'asthme chez les jeunes enfants autochtones de zéro à six ans qui vivent hors réserve était légèrement plus faible que celle de l'ensemble des autres enfants canadiens. Lallaitement, notamment l'allaitement exclusif, protégeait contre l'asthme chez les enfants autochtones, ce qui s'harmonise avec ce qu'on observe chez les enfants non autochtones du Canada. Les interventions en santé publique visant à réduire l'incidence d'asthme chez les jeunes enfants autochtones devraient inclure des programmes de promotion de l'allaitement.

in young Aboriginal children in Canada (9). In the present study, we used the 2006 Aboriginal Children's Survey (ACS) to determine the prevalence of asthma and the association of demographic, environmental and early life factors, including breastfeeding, with asthma in Aboriginal children zero to six years of age.

\section{Study population}

\section{METHODS}

Statistics Canada conducted the ACS from October 2006 to March 2007. A detailed description of the ACS can be found in a Statistics Canada publication (10). Children zero to six years of age with North American Indian, Métis, Inuit or multiple ancestries, living off reserve were selected as the sampling frame of the 2006 ACS based on data from the 2006 Canadian Census long form $(1,10)$. The identification of Aboriginal ancestry was determined by parental or guardians' answers to the four screening questions in the 2006 Census (10). Aboriginal children living in Indian settlements, reserves or institutions were excluded. Information on children and household members were collected from children's parents or guardians using a paper questionnaire, or telephone or personal interviews. Translators

${ }^{1}$ Department of Public Health Sciences, School of Public Health; ${ }^{2}$ Department of Paediatrics, Faculty of Medicine and Dentistry, University of Alberta, Edmonton, Alberta

Correspondence: Dr Ambikaipakan Senthilselvan, School of Public Health, University of Alberta, 3-349 Edmonton Health Clinic Academy,

11405-87 Avenue, Edmonton, Alberta T6G 1C9. Telephone 780-492-6505, fax 780-492 0364, e-mail sentil@ualberta.ca 
or interpreters were available as required. Information on children's health conditions, and social and environmental factors were also collected in the 2006 ACS (10).

A two-phase sampling method was used in the ACS by Statistics Canada, which included initial selection of households with Aboriginal children zero to six years of age and subsequent selection of children from the households. According to Statistics Canada, a total of 18,307 children were sampled for the 2006 ACS. Due to the overlap with four other postcensal surveys (Participation and Activity Limitation Survey, Survey on the Vitality of Official-Language Minorities, Maternity Experiences Survey and National Longitudinal Survey of Children and Youth [NLSCY]), 835 children were excluded from the initial sample, resulting in 17,472 children being sampled for the 2006 ACS (10). Of these 17,472 children, 14,170 returned the questionnaire, yielding a response rate of $81.1 \%$. Based on the responses to the questionnaire, 162 children were not $<6$ years of age, 10 were deceased and one no longer resided in Canada. Instead of excluding these 173 children from the survey, Statistics Canada used sampling weight to adjust these 'out of scope' units.

The present study was approved by the Health Research Ethics Board at the University of Alberta, Edmonton, Alberta.

\section{Study outcomes}

The presence or absence of asthma was determined from the responses to the question: "Does he/she have asthma?" and a subsequent question: "Did he/she get a diagnosis [of asthma] from a doctor, nurse or health professional?" Only children with positive responses to both questions were considered to be those with a report of asthma. Information on receiving treatment for asthma in children with a report of asthma was obtained from the responses to the question: "Has he/she received treatment [of asthma]?" In addition, taking medication for asthma was determined from the response to the question: "Does he/she take any of the following medications: Ventolin, inhalers or puffers for asthma?"

\section{Potential factors associated with asthma}

Information on ever breastfeeding was determined by the response to the following ACS question: "Was he/she ever breast-fed?" In addition to the dichotomous indicator of breastfeeding, the length of breastfeeding (never, one to six months, seven to 12 months, and 12 months or more) was also obtained from the ACS questionnaire. Furthermore, exclusive breastfeeding for at least six months was determined by the responses to the following questions: "Was he/she ever bottle-fed?", "Was he/she ever fed any of the following in his/her bottle [breast milk only, formula milk, soy milk, other milk, juice and other drinks]?" and "For how long?" Other potential factors associated with the development of asthma were selected based on a literature review (4,11-14).

Demographic factors, such as age, sex, ancestry (North American Indian, Métis, Inuit or multiple ancestries), urban or rural residence, and geographical regions of residence (Atlantic, Quebec, Ontario, Prairies, British Columbia, Territories) were included in the analyses. Children were classified into three age groups: zero to one year, two to three years, and four to six years. Early childhood factors, such as low birth weight $(\leq 2500 \mathrm{~g})$ and day care attendance, were also included.

The general health status of Aboriginal children was determined from the responses to the question "In general, would you say his/ her health is?" Possible responses were excellent, very good, good, fair or poor. The responses 'very good' and 'good' were combined in the manuscript. Access to health care was determined from the response to: "Whether or not there was a time when you wanted health care or medication for your child and could not get it during the past 12 months?" The status of 'respiratory allergy' was determined from the response to the two questions: "Does he/she have respiratory allergies (such as hay fever) that have lasted or are expected to last 6 months or more?" and "Did he/she get a diagnosis from a doctor, nurse or health professional?" Smoking inside the home was obtained from the parents' indication that household members or regular visitors smoked inside the home daily or almost daily.
Household factors, such as number of older siblings, dwelling type and condition of dwelling, were included in the analyses. The condition of dwelling was indicated by whether the dwelling was in need of repair at the time of the survey. Socioeconomic factors considered in the present study included household income levels divided into quartiles ( $\leq \$ 30,000 /$ year, $\$ 30,001$ to $\$ 50,000 /$ year, $\$ 50,001$ to $\$ 80,000 /$ year or $>\$ 80,000 /$ year, and the highest education level attained by either parent (lower than high school, high school, or postsecondary or higher).

\section{Statistical analysis}

The outcome variable in the analysis was the presence/absence of asthma indicated by a dichotomous variable. Age, sex, and ancestryspecific prevalence of asthma and 95\% CIs were obtained. Design weights provided by Statistics Canada, for the correction of poststratification in the two-phase sampling, units with no responses, out of scope units and overlaps with other surveys, were incorporated in statistical analyses.

A purposeful selection method was used to select the variables associated with asthma in the multiple logistic regression analysis. The variables that were statistically significant at $P=0.20$ in the univariate logistic regression analysis and other variables that were clinically and/or biologically important were chosen for the multiple logistic regression. The variables that were nonsignificant at $\mathrm{P}=0.05$ were removed after checking for the potential confounding effects of these variables on other variables in the logistic regression model (15). ORs and the $95 \%$ CIs for breastfeeding and other risk factors were calculated using bootstrap weights. Interaction effects between variables were examined in the multiple logistic regression (15). All statistical analyses were performed using STATA release 10 (StataCorp, USA).

\section{Asthma prevalence}

\section{RESULTS}

The prevalence of reported asthma in Aboriginal children zero to six years of age was $9.4 \%$ (95\% CI [8.75\% to $9.99 \%]$ ). Among the children who had a report of asthma, $91.6 \%$ (95\% CI $89.9 \%$ to $93.4 \%$ ) received treatment for asthma and $88.2 \%$ (95\% CI $86.0 \%$ to $90.4 \%$ ) took asthma medications. As shown in Table 1, the prevalence of reported asthma was higher in boys than in girls (11.4\% versus $7.3 \%)$. Asthma prevalence in children with North American Indian, Métis, Inuit and multiple aboriginal ancestries were $10.0 \%, 8.5 \%, 6.6 \%$ and $9.7 \%$, respectively. The prevalence of reported asthma among Métis and Inuit children was significantly lower than that in children with North American Indian ancestry $(\mathrm{P}<0.05)$. Among the 10 provinces and territories in Canada, Quebec had the highest prevalence of asthma and the Territories had the lowest, which were significantly different from the other provinces. Aboriginal children living in urban areas had a significantly higher prevalence of reported asthma than those living in rural areas.

\section{Asthma prevalence and breastfeeding}

As shown in Table 2, 26.2\% of Aboriginal children were never breastfed. The prevalence of reported asthma was significantly lower in both exclusively breastfed children $(6.8 \%)$ and ever but not exclusively breastfed children $(9.0 \%)$ compared with the nonbreastfed children $(11.4 \%)$. Although no clear dose-response relationship was observed between the duration of breastfeeding and asthma, children who were breastfed for one to six months, seven to 12 months or $>12$ months had a lower prevalence of reported asthma than those who were never breastfed, with only the latter category not being significantly different from the nonbreastfed category $(\mathrm{P}=0.08)$.

\section{Asthma prevalence and other early childhood factors}

As shown in Table 2, the prevalence of reported asthma in Aboriginal children with low birth weight $(\leq 2500 \mathrm{~g})$ was approximately twice that in children with a normal birth weight. The prevalence of reported asthma was more than twice as high among children with difficulties in accessing health care compared with those with easy access to health 
TABLE 1

Distribution (distr) of demographic factors and household factors, asthma prevalence (PR) and univariate association

\begin{tabular}{|c|c|c|c|c|}
\hline & $\begin{array}{c}\text { Sample } \\
\text { distr*, \% }\end{array}$ & $\begin{array}{l}\text { Asthma } \\
\text { PR* }^{*} \%\end{array}$ & OR $(95 \% \mathrm{Cl})^{\dagger}$ & $\mathbf{P}$ \\
\hline \multicolumn{5}{|l|}{ Demographic factors } \\
\hline \multicolumn{5}{|l|}{ Age, years } \\
\hline $0-1$ & 28.1 & 4.8 & 1 & \\
\hline $2-3$ & 36.3 & 10.1 & $2.25(1.86-2.73)$ & $<0.0001$ \\
\hline $4-6$ & 35.6 & 12.2 & $2.76(2.28-3.33)$ & $<0.0001$ \\
\hline \multicolumn{5}{|l|}{ Sex } \\
\hline Female & 49.5 & 7.3 & 1 & \\
\hline Male & 50.5 & 11.4 & $1.65(1.42-1.90)$ & $<0.0001$ \\
\hline \multicolumn{5}{|l|}{ Ancestry } \\
\hline NAI & 51.0 & 10.0 & 1 & \\
\hline Métis & 25.0 & 8.5 & $0.84(0.71-1.00)$ & 0.05 \\
\hline Inuit & 5.1 & 6.6 & $0.65(0.50-0.83)$ & $<0.0001$ \\
\hline Multiple ancestries & 18.9 & 9.7 & $0.97(0.80-1.17)$ & 0.72 \\
\hline \multicolumn{5}{|c|}{ Region of residence (Canada) } \\
\hline Atlantic & 6.2 & 9.1 & 1 & \\
\hline Quebec & 12.7 & 12.3 & $1.42(1.00-2.01)$ & 0.05 \\
\hline Ontario & 24.3 & 9.7 & $1.09(0.80-1.47)$ & 0.59 \\
\hline Prairies & 37.6 & 9.2 & $1.03(0.78-1.37)$ & 0.84 \\
\hline British Columbia & 14.2 & 8.1 & $0.89(0.65-1.22)$ & 0.48 \\
\hline Territories & 5.0 & 5.2 & $0.55(0.39-0.77)$ & $<0.0001$ \\
\hline \multicolumn{5}{|l|}{ Residence } \\
\hline Nonurban & 27.0 & 7.9 & 1 & \\
\hline Urban & 73.0 & 9.9 & $1.28(1.08-1.51)$ & $<0.0001$ \\
\hline \multicolumn{5}{|l|}{ Household factors } \\
\hline \multicolumn{5}{|l|}{ Older siblings, $\mathrm{n}$} \\
\hline 0 & 43.9 & 9.1 & 1 & \\
\hline 1 & 35.0 & 9.8 & $1.08(0.92-1.27)$ & 0.33 \\
\hline$\geq 2$ & 21.1 & 9.5 & $1.05(0.87-1.25)$ & 0.62 \\
\hline \multicolumn{5}{|l|}{ Type of dwelling } \\
\hline House & 76.6 & 8.8 & 1 & \\
\hline $\begin{array}{c}\text { Apartment or } \\
\text { movable }\end{array}$ & 23.4 & 11.4 & $1.34(1.14-1.58)$ & $<0.0001$ \\
\hline \multicolumn{5}{|l|}{ Condition of dwelling } \\
\hline No need of repair & 47.6 & 8.8 & 1 & \\
\hline In need of repair & 52.4 & 9.9 & $1.15(0.99-1.33)$ & 0.06 \\
\hline
\end{tabular}

*Survey design weights were used in the estimation of percentages; ${ }^{\dagger}$ Results from the univariate logistic regression. Survey design and 1000 bootstrap weights were included in the estimation in logistic regression. A Fay factor of 0.67 was used to make the transformed bootstrap weights positive. NAI North American Indian

care. Additionally, ear infection was significantly associated with a higher prevalence of asthma.

Children with a respiratory allergy had a substantially higher prevalence of reported asthma compared with children without allergy $(58.7 \%$ versus $8.1 \%, \mathrm{P}<0.0001)$. Age- and sex-specific analyses also showed that children with respiratory allergy were more likely to have a report of asthma than those who did not have respiratory allergy (data not shown). Because of the high prevalence of respiratory allergy among children with asthma and the inability to determine the direction of the association from a cross-sectional study, respiratory allergy was not considered in the multiple logistic regression model.

Asthma prevalence and socioeconomic factors

The prevalence of reported asthma significantly decreased with increases in household income. Asthma prevalence in children whose parents had postsecondary or higher education was significantly lower than children whose parents' education level was less than high school.

TABLE 2

Distribution (distr) of early childhood factors, healthrelated factors and the socioeconomic factors, asthma prevalence (PR) and univariate association

\begin{tabular}{rrrrr}
\hline $\begin{array}{r}\text { Sample } \\
\text { distr*, \% }\end{array}$ & $\begin{array}{c}\text { Asthma } \\
\mathrm{PR}^{*}, \%\end{array}$ & OR $(95 \% \mathrm{Cl})^{\dagger}$ & $\mathbf{P}$
\end{tabular}

\section{Early childhood factors}

Low birth weight

$\begin{array}{lrrcc}>2500 \mathrm{~g} & 7.3 & 8.8 & 1 & \\ \leq 2500 \mathrm{~g} & 92.7 & 16.1 & 1.83(1.44-2.31) & <0.0001 \\ \text { Breastfeeding } & & & & \\ \quad \text { No } & 26.2 & 11.4 & 1 & \\ \quad \begin{array}{l}\text { Ever but not } \\ \quad \text { exclusively }\end{array} & 61.5 & 9.0 & 0.77(0.65-0.91) & 0.002 \\ \quad \text { Exclusively } & 12.3 & 6.8 & 0.56(0.43-0.74) & <0.0001 \\ \text { Duration of breastfeeding, months } & & & \\ \text { Never } & 26.2 & 11.4 & 1 & \\ \begin{array}{l}\text { 1-6 } \\ \text { 7-12 }\end{array} & 40.9 & 9.2 & 0.79(0.66-0.94) & 0.01 \\ >12 & 21.4 & 8.7 & 0.74(0.60-0.92) & 0.01 \\ \text { Day care attendance } & 11.6 & 9.2 & 0.78(0.60-1.03) & 0.08 \\ \text { No } & & & & \\ \text { Yes } & 50.4 & 7.6 & 1 & \\ \end{array}$

Health-related factors

General health status

Excellent

Very good or good

Fair

3.7

1

Fair

$5.48(4.62-6.49)<0.0001$

Poor

39.2

16.7 $<0.0001$

(12.61-21.16)

Access to health care

Limited

$14.5(7.76-27.21)<0.0001$

\section{Easy}

$\begin{array}{rr}7.6 & 19.5 \\ 92.4 & 8.6\end{array}$

\section{1}

Respiratory allergy

$$
\text { No }
$$

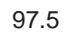

8.1

Yes

Ear infection

No

Yes

Smoke inside home

No

Yes

48.7

51.3

5.4

13.1

82.5

17.5

9.2

9.8

Socioeconomic factors

Household income/year, $\$$

$\leq 30,000$
$30,001-50,000$
$50,001-80,000$

*Survey design weights were used in the estimation of percentages; ${ }^{\dagger}$ Results from the univariate logistic regression. Survey design and 1000 bootstrap weights were included in the estimation in logistic regression. A Fay factor of 0.67 was used so that the transformed bootstrap weights would be positive 


\begin{tabular}{|c|c|c|}
\hline & OR $(95 \% \mathrm{Cl})$ & $\mathbf{P}$ \\
\hline \multicolumn{3}{|l|}{ Age, years } \\
\hline $0-1$ & 1 & \\
\hline $2-3$ & $2.10(1.71-2.58)$ & $<0.0001$ \\
\hline $4-6$ & $2.53(2.06-3.12)$ & $<0.0001$ \\
\hline \multicolumn{3}{|l|}{ Sex } \\
\hline Female & 1 & \\
\hline Male & $1.67(1.43-1.95)$ & $<0.0001$ \\
\hline \multicolumn{3}{|l|}{ Ancestry } \\
\hline North American Indian & 1 & \\
\hline Métis & $0.87(0.73-1.05)$ & 0.16 \\
\hline Inuit & $0.64(0.47-0.86)$ & 0.003 \\
\hline Multiple ancestries & $0.97(0.79-1.19)$ & 0.75 \\
\hline \multicolumn{3}{|l|}{ Older siblings, $\mathrm{n}$} \\
\hline 0 & 1 & \\
\hline 1 & $1.13(0.96-1.34)$ & 0.15 \\
\hline$\geq 2$ & $1.26(1.04-1.54)$ & 0.02 \\
\hline \multicolumn{3}{|l|}{ Type of dwelling } \\
\hline House & 1 & \\
\hline Apartment or movable & $1.47(1.23-1.76)$ & $<0.0001$ \\
\hline \multicolumn{3}{|l|}{ Access to health care } \\
\hline Limited & 1 & \\
\hline Easy & $0.42(0.34-0.52)$ & $<0.0001$ \\
\hline \multicolumn{3}{|l|}{ Low birth weight } \\
\hline$>2500 \mathrm{~g}$ & 1 & \\
\hline$\leq 2500 \mathrm{~g}$ & $1.70(1.32-2.20)$ & $<0.0001$ \\
\hline \multicolumn{3}{|l|}{ Breastfeeding } \\
\hline No & 1 & \\
\hline Ever but not exclusively & $0.84(0.70-1.01)$ & 0.065 \\
\hline Exclusively & $0.59(0.44-0.78)$ & $<0.0001$ \\
\hline \multicolumn{3}{|l|}{ Day care attendance } \\
\hline No & 1 & \\
\hline Yes & $1.32(1.13-1.55)$ & 0.001 \\
\hline \multicolumn{3}{|l|}{ Ear infection } \\
\hline No & 1 & \\
\hline Yes & $2.17(1.82-2.58)$ & $<0.0001$ \\
\hline
\end{tabular}

*Survey design and 1000 bootstrap weights were included in the estimation in logistic regression. A Fay factor of 0.67 was used so that the transformed bootstrap weights would be positive. $P=0.24$ for the Hosmer-Lemeshow goodness of fit test for the final model

Results from the multiple logistic regression analysis

As shown in Table 3, risk factors for asthma included older age group, male sex, living in an apartment or movable dwelling, two or more older siblings, low birth weight, day care attendance and ear infection. Children who were exclusively breastfed had a $41 \%$ reduction in the odds of a report of asthma compared with children who were not breastfed (OR 0.59 [95\% CI 0.44 to 0.78]). Children who were ever breastfed but not exclusively had a $16 \%$ marginally significant reduction in the odds of having asthma compared with the nonbreastfed children (OR 0.84 [95\% CI 0.70 to 1.01]). Easy access to health care in the past 12 months was a protective factor for asthma. Children with a history of ear infection had an almost twofold increase in the odds of a report of asthma compared with those without a history of ear infection. None of the interaction effects were significant in the multiple logistic regression analysis.

\section{DISCUSSION}

To the best of our knowledge, the present study was the first to investigate the prevalence of asthma and the relationship between asthma and breastfeeding and other early life factors in Aboriginal children zero to six years of age using a large representative sample of Canadian Aboriginal population living off reserve. In the present populationbased study, the prevalence of reported asthma among young Aboriginal children living off reserve was $9.4 \%$, slightly lower than that reported for all other Canadian children in the same age group (9.9\%) in the NLSCY, which used the same methodology and questions to define asthma as in the 2006 ACS (16).

Children two to five years of age had a higher prevalence of asthma than infants in our study, which was consistent with figures reported in the NLSCY (16). However, the wheezing patterns may have been different between infants and older children in our study. This could not be verified in our study because the information on asthma-related symptoms, such as current, recurrent and persistent wheezing, was not available in the 2006 ACS.

A study using a physician service database in Saskatchewan reported that asthma prevalence was highest in registered Indian children compared with other children zero to four years of age (17). We also found that Inuit children, especially those living in Northern Canadian Territories, had the lowest prevalence of asthma (data not shown). The lower prevalence of asthma in Inuit children may be related to the differences in lifestyle, dietary and genetic factors among Inuit and other Aboriginal populations.

In our study, $73.8 \%$ of Aboriginal children were ever breastfed when they were infants, which is comparable with the Canadian national average (75\%) (18). However, it was much higher than that reported in the First Nations and Inuit Regional Health Survey (54\%) (9). Early childhood experiences such as bacterial infections, allergen exposure and vaccinations, which may include changes in the programming of children's immune systems, are important for children's susceptibility to asthma (19). Bioactive substances in breast milk, such as oligosaccharides, glycans and lactoferrin, have protective roles in the infant immune system (20-23). In addition, levels of anti-infection immunoglobulin A antibodies and immunoregulatory cytokines, including interferon-alpha and transforming growth factor-beta, were reported to be higher in the breast milk than in the maternal blood $(24,25)$. Genetic factors, such as genes involved in the uptake and metabolism of fatty acids from breast milk, may modulate the protective effect of breastfeeding against asthma (26). According to the WHO and Health Canada recommendations, exclusive breastfeeding for at least six months was optimal for infant nutrition $(27,28)$. In our study, children who were exclusively breastfed experienced a greater protective effect against childhood asthma than children who were not exclusively breastfed.

However, results from studies examining the association of breastfeeding and asthma remain contradictory (5-7,29). In our study, breastfeeding, especially exclusively breastfeeding for at least six months, was protective of asthma in Aboriginal children zero to six years of age, which was consistent with many other studies $(4-6,14)$. The protective effect of breastfeeding on the development of asthma was also reported in a large Canadian birth cohort study of infants and toddlers (4). Nevertheless, breastfeeding was a significant risk factor for early childhood and intermittent wheezing but not for persistent wheezing in a Canadian cohort study of infants and toddlers (30). In a recent report from the ISAAC-Phase III trial, there was no consistent evidence supporting the association between breastfeeding and asthma, either as a protective or risk factor $(8,31)$.

In our study, prolonged breastfeeding ( $>6$ months) was not significantly associated with asthma. However, a population-based study from Canada (32) showed a dose-response relationship between the duration of breastfeeding and asthma, with longer duration of breastfeeding being protective for childhood asthma. In a cluster-randomized trial conducted in Canada (33), there was no significant reduction in the risk of asthma associated with prolonged and exclusive breastfeeding. A cohort study from Finland (34) reported a U-shape relationship between the duration of breastfeeding and risk of asthma with an optimal protective effect at four to six months. Several factors, 
including maternal and/or paternal atopy, have been reported to be potential modifiers of the relationship between breastfeeding and asthma $(8,35,36)$. Lack of consideration of potential confounders and effect modifiers may also have resulted in the observed inconsistencies among studies on breastfeeding and asthma.

Consistent with other studies $(37,38)$, our study showed that respiratory allergy was the most influential factor associated with asthma. In our study, the strength of the association between respiratory allergy and asthma in Aboriginal children zero to six years of age was much higher than those reported in children of older ages (39). It is possible that our study identified more children with atopic asthma than children with nonatopic asthma, a condition associated with transient wheezing (40).

First-born children have been reported to have a higher risk of asthma early in their lives $(4,41)$. However, the present study showed that having older siblings was a risk factor for asthma in Aboriginal children. A systematic review suggested that multiple factors were involved in determining the direction of the sibling effect on asthma including mother's utero programming, children's prenatal endocrine modulation, postnatal care and environmental factors (42).

In our study, day care attendance was associated with an increased risk of asthma in young Aboriginal children. A Swedish study showed that day care attendance was positively associated with asthmatic, allergic and respiratory symptoms in preschool children (43). However, there have been conflicting findings regarding the relationship between day care attendance and asthma and asthma-like symptoms $(12,44,45)$. The differences in genetic predisposition to allergy and in the maturity of the immune system at the ages when children attend day care may be related to the inconsistent findings among studies (46).

Aboriginal people were known to have a generally lower level of self-assessed health status, which was more likely due to the inadequate resources and limited access to health care services in Aboriginal communities (47). In the univariate analysis, we found that the prevalence of asthma among children with difficulty in accessing health care was more than twice that among those with easy access to health care, raising the possibility that access to adequate health care improves the overall health of Aboriginal children and may reduce asthma morbidity among these children.

\section{REFERENCES}

1. Aboriginal Children's Survey, 2006: Family, Community and Child Care. 2006 [cited 2011 July 08]; <www.statcan.gc.ca/bsolc/olc-cel/ olc-cel?lang $=$ eng\& $\&$ catno $=89-634-X 2008001>($ Accessed September 10, 2012)

2. An Overview of the Health of the Métis Population: Fact Sheet. Catalogue no. 89-637-X, No 6. 2006 [cited 2011 July 08]; <www.statcan.gc.ca/pub/89-637-x/2009006/art/art1-eng.htm> (Accessed September 10, 2012).

3. Aboriginal People Survey, 2006: Inuit Health and Social Conditions. Catalogue no. 89-637-X, No 1. 2006 [cited 2011 July 08]; <www.statcan.gc.ca/bsolc/olc-cel/olc-cel?catno=89-637XWE2008001\&lang=eng $>$ (Accessed September 10, 2012).

4. Midodzi WK, Rowe BH, Majaesic CM, Saunders LD, Senthilselvan A. Early life factors associated with incidence of physician-diagnosed asthma in preschool children: Results from the Canadian Early Childhood Development cohort study. J Asthma 2010;47:7-13.

5. Chulada PC, Arbes SJ Jr, Dunson D, Zeldin DC. Breast-feeding and the prevalence of asthma and wheeze in children: Analyses from the Third National Health and Nutrition Examination Survey, 1988-1994. J Allergy Clin Immunol 2003;111:328-36.

6. Oddy WH. Breastfeeding and asthma in children: Findings from a West Australian study. Breastfeed Rev 2000;8:5-11.

7. Wright AL, Holberg CJ, Taussig LM, Martinez FD. Factors influencing the relation of infant feeding to asthma and recurrent wheeze in childhood. Thorax 2001;56:192-7.

8. Bjorksten B, Ait-Khaled N, Innes Asher M, Clayton TO, Robertson C. Global analysis of breast feeding and risk of symptoms of asthma,
There were some limitations to our study. First, according to the 2006 Aboriginal People's Survey, 30.5\% of Aboriginal children $<6$ years of age living on reserves were not included in our study (48). Results from the Regional Health Survey conducted among Aboriginal populations living on reserve supplement the findings from our study (49). Second, the prevalence of asthma was based on a parental report of the diagnosis of asthma by a health professional in the 2006 ACS, which was not confirmed by clinical chart review or objective testing. In addition, the high prevalence of wheezing and complexity in asthma diagnosis among young children often leads to the overdiagnosis of asthma $(50,51)$. Although still difficult and controversial in the diagnosis of asthma in young children, several studies have shown that the parental report of asthma diagnosis by health professionals in children has acceptable sensitivity and specificity $(52,53)$. Finally, due to the cross-sectional nature of the 2006 ACS, the temporal sequence between asthma incidence and risk factors was not known, making it very difficult to establish causal inferences.

\section{CONCLUSION}

Asthma prevalence among young Aboriginal children living off reserve was slightly lower than that reported for other children in Canada. Similar to the results from Canadian studies involving non-Aboriginal children, breastfeeding was protective against asthma, while male sex, low birth weight, ear infection and day care attendance were associated with an increased risk of asthma. Public health interventions intended for reducing asthma incidence in young Aboriginal children should include breastfeeding promotion programs.

DISCLAIMER: The research and analysis were based on the data from Statistics Canada and opinions expressed herein do not represent the views of Statistics Canada.

ACKNOWLEDGEMENTS: MY was supported by the Canadian Institutes of Health Research (CIHR)-PHARE (Public Health and the Agricultural Rural Ecosystem) graduate training program and a Queen Elizabeth II Graduate Studentship offered by the University of Alberta.

DISCLOSURES: The authors have no financial disclosures or conflicts of interest to declare. rhinoconjunctivitis and eczema in 6-7 year old children: ISAAC Phase Three. Allergol Immunopathol (Madr) 2011;39:318-25.

9. MacMillan HL, Jamieson E, Walsh C, Boyle M, Crawford A, MacMillan A. The health of Canada's Aboriginal children: Results from the First Nations and Inuit Regional Health Survey. Int J Circumpolar Health 2010;69:158-67.

10. Aboriginal Children's Survey, 2006: Concepts and Methods Guide. 2006 [cited 2011 July 08]; <www.statcan.gc.ca/bsolc/olc-cel/olccel?lang $=$ eng\& $\&$ atno $=89-634-X 2008006>($ Accessed September 10, 2012).

11. Postma DS. Gender differences in asthma development and progression. Gend Med 2007;(4 Suppl B):S133-46.

12. Celedon JC, Wright RJ, Litonjua AA, et al. Day care attendance in early life, maternal history of asthma, and asthma at the age of 6 years. Am J Respir Crit Care Med 2003;167:1239-43.

13. Gao Z, Rowe BH, Majaesic C, O'Hara C, Senthilselvan A. Prevalence of asthma and risk factors for asthma-like symptoms in Aboriginal and non-Aboriginal children in the northern territories of Canada. Can Respir J 2008;15:139-45.

14. Scholtens S, Wijga AH, Brunekreef B, et al. Breast feeding, parental allergy and asthma in children followed for 8 years. The PIAMA birth cohort study. Thorax 2009;64:604-9.

15. Hosmer D, Lemeshow S. Applied Logistic Regression. New York: Wiley; 2000.

16. Garner R, Kohen D. Changes in the prevalence of asthma among Canadian children. 2008 [cited 2011 July 08]; <www.statcan.gc.ca/ 
pub/82-003-x/2008002/article/10551-eng.pdf> (Accessed September 10, 2012).

17. Senthilselvan A, Lawson J, Rennie DC, Dosman JA. Stabilization of an increasing trend in physician-diagnosed asthma prevalence in Saskatchewan, 1991 to 1998 . Chest 2003;124:438-48.

18. McIntyre L. Growing up in Canada: National Longitudinal Survey of Children and Youth. Ottawa: Statistics Canada, 1996:47-56.

19. Holt PG, Sly PD. Allergic respiratory disease: Strategic targets for primary prevention during childhood. Thorax 1997;52:1-4.

20. M'Rabet L, Vos AP, Boehm G, Garssen J. Breast-feeding and its role in early development of the immune system in infants:

Consequences for health later in life. J Nutr 2008;138:1782S-90S.

21. Hosea Blewett HJ, Cicalo MC, Holland CD, Field CJ.

The immunological components of human milk. Adv Food Nutr Res 2008;54:45-80.

22. Newburg DS. Neonatal protection by an innate immune system of human milk consisting of oligosaccharides and glycans. J Anim Sci 2009;87(13 Suppl):26-34.

23. Mattsby-Baltzer I, Roseanu A, Motas C, Elverfors J, Engberg I, Hanson LA. Lactoferrin or a fragment thereof inhibits the endotoxin-induced interleukin-6 response in human monocytic cells. Pediatr Res 1996;40:257-62.

24. Eglinton BA, Roberton DM, Cummins AG. Phenotype of T cells, their soluble receptor levels, and cytokine profile of human breast milk. Immunol Cell Biol 1994;72:306-13.

25. Goldman AS. The immunological system in human milk: The past - a pathway to the future. Adv Nutr Res 2001;10:15-37.

26. Standl M, Sausenthaler S, Lattka E, et al. FADS gene cluster modulates the effect of breastfeeding on asthma. Results from the GINIplus and LISAplus studies. Allergy 2012;67:83-90.

27. Nutrition for a Healthy Pregnancy: National Guidelines for the Childbearing Years. 1999 [cited 2012 April 03, 2012]; <www.hc-sc.gc.ca/fn-an/pubs/nutrition/guide-prenatal-eng.php> (Accessed September 10, 2012).

28. Exclusive breastfeeding. 2012 [cited 2012 April 03, 2012]; $<$ www.who.int/nutrition/topics/exclusive_breastfeeding/en/> (Accessed September 10, 2012).

29. Sears MR, Greene JM, Willan AR, et al. Long-term relation between breastfeeding and development of atopy and asthma in children and young adults: A longitudinal study. Lancet 2002;360:901-7.

30. Midodzi WK, Rowe BH, Majaesic CM, Saunders LD, Senthilselvan A. Predictors for wheezing phenotypes in the first decade of life. Respirology 2008;13:537-45.

31. Brew BK, Allen CW, Toelle BG, Marks GB. Systematic review and meta-analysis investigating breast feeding and childhood wheezing illness. Paediatr Perinat Epidemiol 2011;25:507-18.

32. Dell S, To T. Breastfeeding and asthma in young children: Findings from a population-based study. Arch Pediatr Adolesc Med 2001;155:1261-5.

33. Kramer MS, Matush L, Vanilovich I, et al. Effect of prolonged and exclusive breast feeding on risk of allergy and asthma: Cluster randomised trial. BMJ 2007;335:815.

34. Fredriksson P, Jaakkola N, Jaakkola JJ. Breastfeeding and childhood asthma: A six-year population-based cohort study. BMC Pediatr 2007;7:39.
35. Mandhane PJ, Greene JM, Sears MR. Interactions between breastfeeding, specific parental atopy, and sex on development of asthma and atopy. J Allergy Clin Immunol 2007;119:1359-66.

36. Wright AL, Holberg CJ, Taussig LM, Martinez F. Maternal asthma status alters relation of infant feeding to asthma in childhood. Adv Exp Med Biol 2000;478:131-7.

37. Illi S, von Mutius E, Lau S, et al. The natural course of atopic dermatitis from birth to age 7 years and the association with asthma. J Allergy Clin Immunol 2004;113:925-31.

38. Nickel R, Lau S, Niggemann B, et al. Messages from the German Multicentre Allergy Study. Pediatr Allergy Immunol 2002;(13 Suppl 15):7-10.

39. Lawson JA, Rennie DC, Senthilselvan A, Cockcroft DW, $\mathrm{McDuffie} \mathrm{HH}$. Regional variations in risk factors for asthma in school children. Can Respir J 2005;12:321-6.

40. Henderson J, Granell R, Heron J, et al. Associations of wheezing phenotypes in the first 6 years of life with atopy, lung function and airway responsiveness in mid-childhood. Thorax 2008;63:974-80.

41. Ball TM, Castro-Rodriguez JA, Griffith KA, Holberg CJ, Martinez FD, Wright AL. Siblings, day-care attendance, and the risk of asthma and wheezing during childhood. N Engl J Med 2000;343:538-43.

42. Karmaus W, Botezan C. Does a higher number of siblings protect against the development of allergy and asthma? A review. J Epidemiol Community Health 2002;56:209-17.

43. Hagerhed-Engman L, Bornehag CG, Sundell J, Aberg N. Day-care attendance and increased risk for respiratory and allergic symptoms in preschool age. Allergy 2006;61:447-53.

44. Rusconi F, Galassi C, Bellasio M, et al. [Risk factors in the pre-, perinatal and early life (first year) for wheezing in young children]. Epidemiol Prev 2005;29(2 Suppl):47-51.

45. Infante-Rivard C, Amre D, Gautrin D, Malo JL. Family size, daycare attendance, and breastfeeding in relation to the incidence of childhood asthma. Am J Epidemiol 2001;153:653-8.

46. Celedon JC, Litonjua AA, Ryan L, Weiss ST, Gold DR. Day care attendance, respiratory tract illnesses, wheezing, asthma, and total serum IgE level in early childhood. Arch Pediatr Adolesc Med 2002;156:241-5.

47. Newbold KB. Aboriginal physician use in Canada: Location, orientation and identity. Health Economics 1997:197-207.

48. Aboriginal Peoples Survey, 2006. [cited 2011 July 08]; $<$ www.statcan.gc.ca/bsolc/olc-cel/olc-cel?lang=eng\& catno=89. 637-X> (Accessed September 10, 2012).

49. RHS Phase 1(2002/03). 2011 [cited 2011 Sep 13]; $<$ www.rhs-ers.ca/node/37> (Accessed September 10, 2012).

50. Wright AL. Epidemiology of asthma and recurrent wheeze in childhood. Clin Rev Allergy Immunol 2002;22:33-44.

51. Chang C. Asthma in children and adolescents: A comprehensive approach to diagnosis and management. Clin Rev Allergy Immunol 2012;43:98-137.

52. Jenkins MA, Clarke JR, Carlin JB, et al. Validation of questionnaire and bronchial hyperresponsiveness against respiratory physician assessment in the diagnosis of asthma. Int J Epidemiol 1996;25:609-16.

53. Yang CL, To T, Foty RG, Stieb DM, Dell SD. Verifying a questionnaire diagnosis of asthma in children using health claims data. BMC Pulm Med 2011;11:52. 


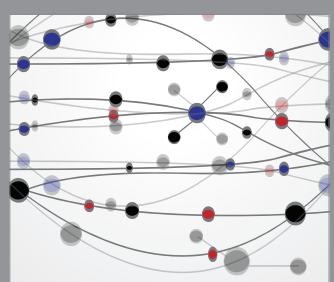

The Scientific World Journal
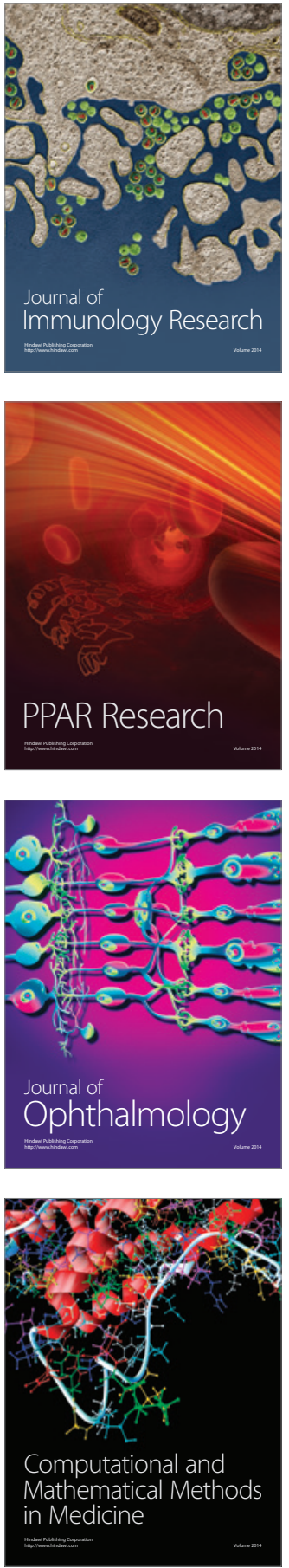

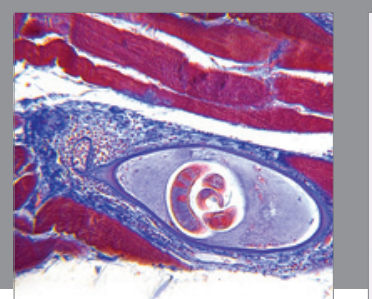

Gastroenterology Research and Practice

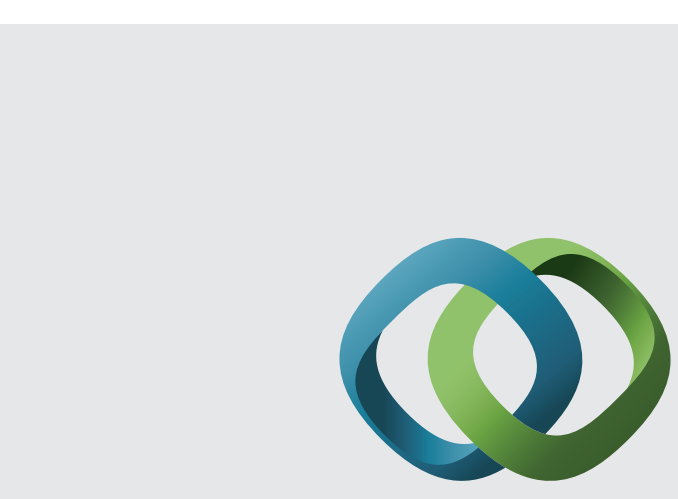

\section{Hindawi}

Submit your manuscripts at

http://www.hindawi.com
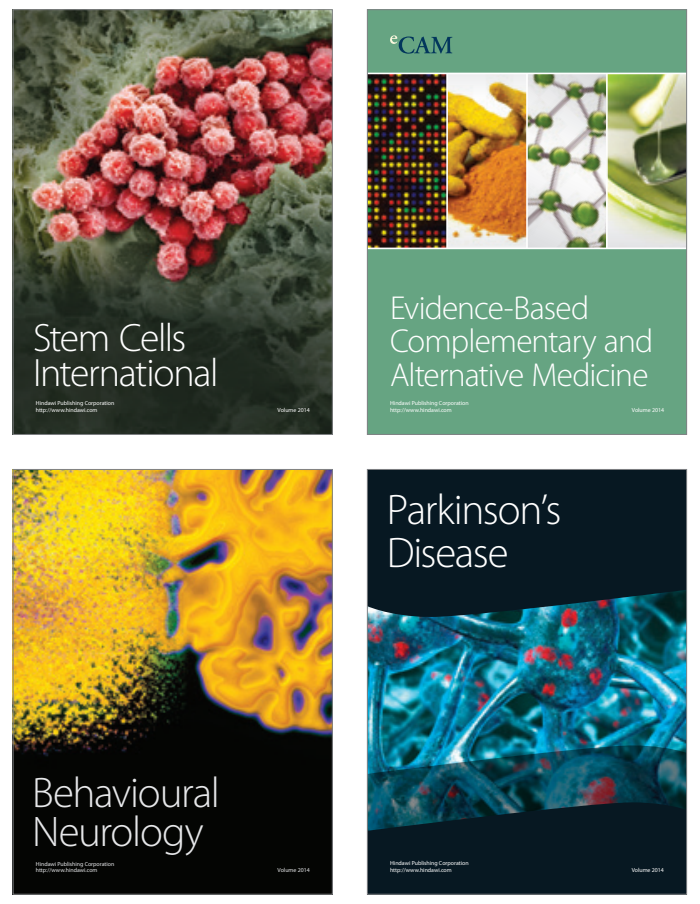
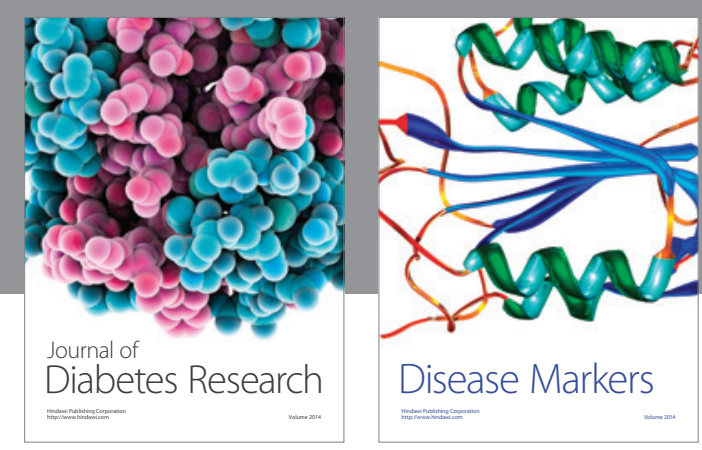

Disease Markers
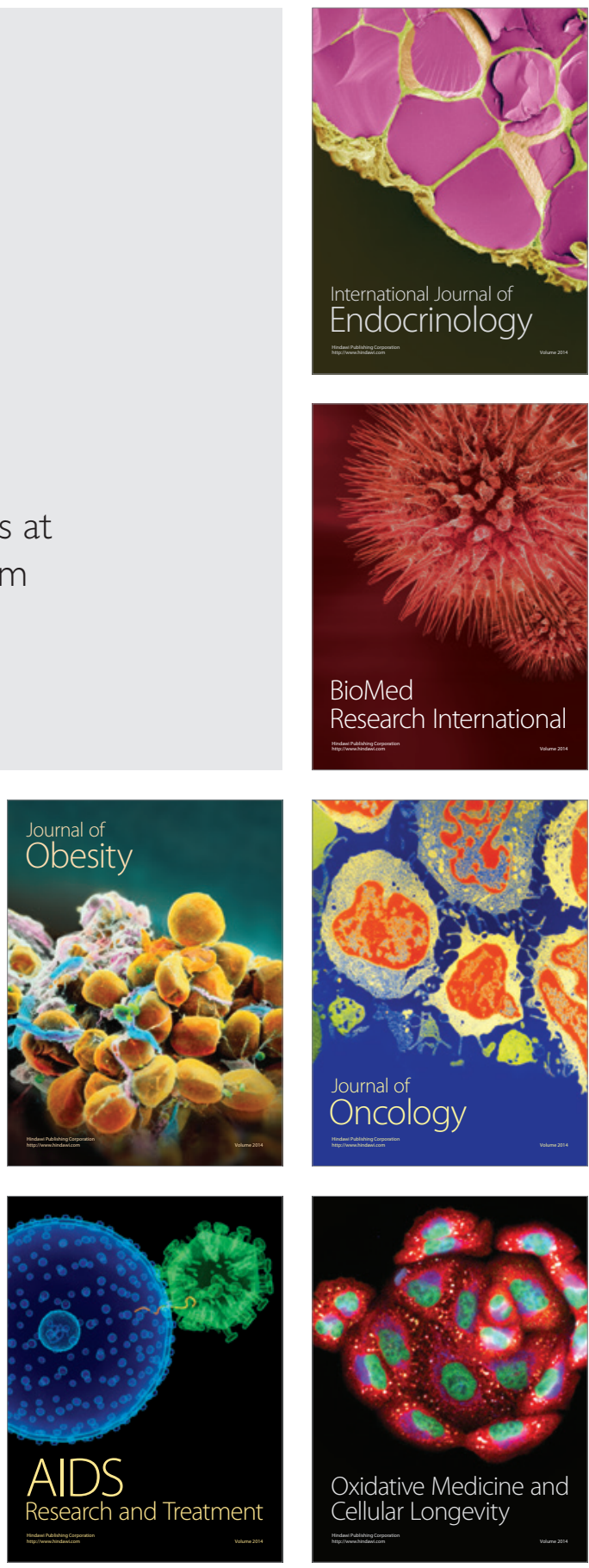